\title{
Correction: A Self-Help App for Syrian Refugees With Posttraumatic Stress (Sanadak): Randomized Controlled Trial
}

Susanne Röhr ${ }^{1,2 *}, \mathrm{PhD}$; Franziska U Jung ${ }^{1 *}, \mathrm{PhD}$; Alexander Pabst ${ }^{1}, \mathrm{PhD}$; Thomas Grochtdreis ${ }^{3}, \mathrm{PhD}$; Judith Dams ${ }^{3}$, $\mathrm{PhD}$; Michaela Nagl ${ }^{4}, \mathrm{PhD}$; Anna Renner ${ }^{4}, \mathrm{MA}$; Rahel Hoffmann ${ }^{4}$, MSc; Hans-Helmut König ${ }^{3}$, MD, PhD; Anette Kersting $^{4}$, MD, PhD; Steffi G Riedel-Heller ${ }^{1}$, MPH, MD, PhD

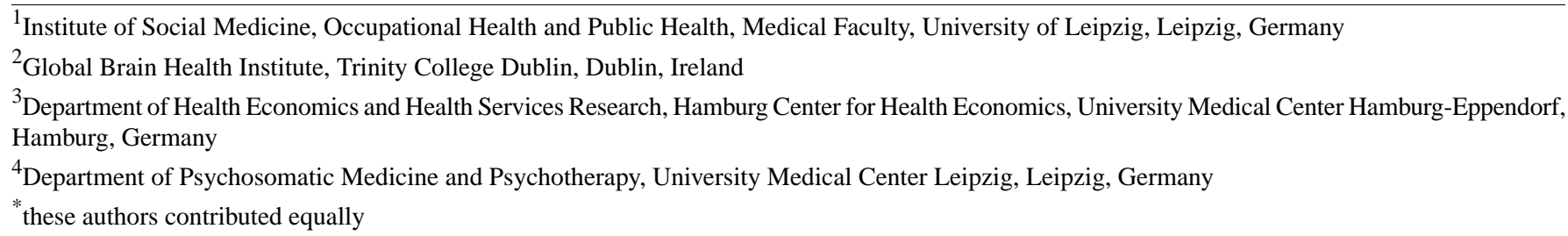

\section{Corresponding Author:}

Susanne Röhr, PhD

Institute of Social Medicine, Occupational Health and Public Health

Medical Faculty, University of Leipzig

Philipp-Rosenthal-Strasse 55

Leipzig

Germany

Phone: 493419724568

Email: susanne.roehr@medizin.uni-leipzig.de

\section{Related Article:}

Correction of: https://mhealth.jmir.org/2021/1/e24807/

(JMIR Mhealth Uhealth 2021;9(3):e28336) doi: 10.2196/28336

In "A Self-Help App for Syrian Refugees With Posttraumatic Stress (Sanadak): Randomized Controlled Trial" (JMIR Mhealth Uhealth 2021;9(1):e24807) one error was noted.

In Table 4, in the row "ED-5D-5L" and sub-row "4 weeks", under the final column "95\% CI", the correct value was not rendered and appeared only as " $\mathrm{t}$ ". This value has been corrected to " -0.189 to 0.556 ".
The correction will appear in the online version of the paper on the JMIR Publications website on March 5, 2021, together with the publication of this correction notice. Because this was made after submission to PubMed, PubMed Central, and other full-text repositories, the corrected article has also been resubmitted to those repositories.

This is a non-peer-reviewed article. Submitted 01.03.21; accepted 03.03.21; published 05.03.21.

Please cite as:

Röhr S, Jung FU, Pabst A, Grochtdreis T, Dams J, Nagl M, Renner A, Hoffmann R, König HH, Kersting A, Riedel-Heller SG Correction: A Self-Help App for Syrian Refugees With Posttraumatic Stress (Sanadak): Randomized Controlled Trial JMIR Mhealth Uhealth 2021;9(3):e28336 URL: https://mhealth.jmir.org/2021/3/e28336

doi: $\underline{10.2196 / 28336}$

PMID: 33667178

(C)Susanne Röhr, Franziska U Jung, Alexander Pabst, Thomas Grochtdreis, Judith Dams, Michaela Nagl, Anna Renner, Rahel Hoffmann, Hans-Helmut König, Anette Kersting, Steffi G Riedel-Heller. Originally published in JMIR mHealth and uHealth (http://mhealth.jmir.org), 05.03.2021. This is an open-access article distributed under the terms of the Creative Commons Attribution License (https://creativecommons.org/licenses/by/4.0/), which permits unrestricted use, distribution, and reproduction in any medium, provided the original work, first published in JMIR mHealth and uHealth, is properly cited. The complete bibliographic 
information, a link to the original publication on http://mhealth.jmir.org/, as well as this copyright and license information must be included. 